\title{
Professionalism as an Indicator of the Success of Bureaucratic Activities
}

\author{
Raden Imam Al Hafis \\ Lecturer at Public Administration Program \\ Fuculty of Social and Politic Science \\ Islamic University of Riau \\ Pekanbaru - Riau - Indonesia \\ imamalhafis@soc.uir.ac.id
}

\begin{abstract}
Various efforts to achieve good governance and clean government are included in the implementation of public services. The rise of problems that occurred in the existing bureaucracy in Indonesia is a government officer who is not professional in carrying out its activities as a state apparatus. Based on the fact that in the world of bureaucracy reinforced by the arguments of experts it can be concluded that the professionalism of government officials is the key to success in the success of bureaucratic activities, which included in the professionalism of bureaucrats, among others on organizational culture, organizational goals, organizational structure, work procedures in bureaucracy, application of merit system.
\end{abstract}

Keywords: Professionalism, purpose, structure, procedure, merit system.

\section{Introduction}

Various efforts to realize the implementation of Good Government and Clean Government including in the implementation of public services requires fundamental elements, among others, is the element of professionalism of the perpetrators and administrators. Ignoring the attitude of professionalism in carrying out the duties, functions and responsibilities as a state servant of the government organization will have an impact on the weak and degradation of the quality of governance, and even rarely will degradation of responsibilities, as state apparatus whose main function as public servant. So it is not uncommon public confidence will increasingly minipis to the government if the government is unable to show a professional attitude in carrying out these duties and responsibilities. The professionalism referred to in this discussion is more directed to the apparatus's ability to provide good, fair, inclusive service and not just a skill match with the place of assignment but also has a responsive attitude. So the demands for the apparatus to have the ability and expertise to understand and translate the aspirations and needs of the community into activities and service programs. The emergence of various obstacles in bureaucracy is often referred to as bureaucratic pathology. The concept of bureaucratic pathology is derived from medical science that examines the diseases attached to human rgan so as to cause the malfunction of these organs. pathology is the discussion here understood as a study in the field of public administration to understand the various diseases inherent in a bureaucracy that led to bureaucracy experiencing dysfunction. [4].
The rise of problems that have occurred lately is related to the unprofessional state apparatus in carrying out their duties and responsibilities even they position themselves not as servants of society but as "kings" to be served and respected. These deep-rooted minds and deeply ingrained habits indirectly affect their behavior and attitude as civil servants in performing their duties.

\section{Indicators of Professionalism.}

Efforts to find a new paradigm in improving the apparatus professionalism associated with the achievement of organizational goals is not an easy job then the ability of the apparatus to adapt to the phenomenon that occurs is the answer to the problem. The importance of the ability of the apparatus in adapting to changes in the external and internal environment of the organization is used as a benchmark in looking at bureaucratic professionalism.

About the measurement of professionalism as follows; Adaptability, Ability to adapt to global phenomena and national phenomena; Referring to the mission and values, the Bureaucracy positioned itself as a service provider to the public and in realizing the organization-oriented goals to the results to be achieved organization. [1].

Professionalism is measured through the expertise possessed by someone who suits the needs of the tasks that the organization imposes on a person. The reason for the importance of a match between a discipline or a skill possessed by a person because if a person's expertise is not in accordance with the tasks assigned to him will have an impact on the organization's effectiveness.

Bureaucratic views can be said to be professional or not, measured through the following competencies, [14];

a. Ability of Entrepreneurship

The ability to see opportunities for enhancing national economic growth, taking risks in taking advantage of opportunities, and the ability to shift the allocation of resources from low productivity activities to open high productivity and provide opportunities for employment creation and increased national income.

b. Ability Lead to Mission

Ability to take decisions and necessary steps and refer to the mission to be achieved, and not simply refer to the applicable regulations.

c. Ability to Empowerment

This capability is required for the executing apparatus or lower ranks that serve to provide public services. 
The professionalism required in this case is professionalism-empowerment that is closely related to the style of development. In this concept, bureaucracy acts as a facilitator or improves people's ability to grow in their own strength. [9].

Professionalism is measured in terms of its speed in performing functions and refers to simplified procedures. [11].

\section{Determinants of Professionalism.}

One of the factors that inhibits the smoothness and effectiveness of public bureaucracy is the unprofessional apparatus of public bureaucracy in performing functions and duties. The unprofessional apparatus of the Indonesian public bureaucracy can be seen from the many findings of the experts and the personal experience of the community in the field of public services organized by the bureaucracy. The sluggishness of the bureaucracy in responding to the public aspirations and the overly procedural service are few examples among the many irregularities in the Indonesian public bureaucracy.

Factors that hamper the creation of professional apparatus are, among other things, due to the fact that apparatus professionalism is often hampered by the absence of a conducive climate in the bureaucratic world to respond to the aspirations of the people and the lack of willingness of the leader to empower the subordinates. This opinion holds that the system of public bureaucratic work based on operational and technical guidelines makes the apparatus unresponsive and also because the role of the leader is not as a director (catalyst) and empowerment for subordinates, [11].

Professionalism is not only adequately shaped and influenced by the expertise and knowledge that the authorities can perform their duties and functions effectively and efficiently, but also influenced by bureaucracy, values, structures, and procedures in the bureaucracy, [14]

To realize the professional apparatus, political will is required from the government to make major changes in public bureaucracy organization in order to work professionally and responsive to public aspirations and needs. These changes include changes in the philosophy or way of view of the organization in achieving the goals that begin by formulating the vision and mission that the organization wants to achieve and run, building a flat and not too hierarchical structure and work procedures that are not too tied to formal rules.

Efforts to realize it is necessary to apply modern management to institutional arrangement as one of the global trends. To fundamentally develop and transform government organizational systems to create dramatic improvements in effectiveness, efficiency, and innovation capabilities it must be achieved through: goal change, merit system, accountability, power structure, and system culture and government organization. [9].

In the opinion it can be concluded that to make changes in the organization and improve the professionalism of the apparatus it is important to redefine what the organization wants to achieve, build a payroll system that put forward the value of justice and build organizational structure that allows for the rapid decision-making process.

Overall, based on the fact that there is in the world of bureaucracy reinforced by the arguments and findings of the theorists it can be concluded that the professionalism of government officials is the key to success in the success of public service, while included in the professionalism of bureaucrats, among others, concerning organizational culture that arises and crystallize in routine bureaucracy, organizational goals, organizational structure, work procedures in bureaucracy, and application of system merit.

\section{Responsiveness}

It is undeniable that environmental changes such as changing attitudes and increasing community demands and rapid technological advances have brought about changes in various aspects and aspects of life. The consequences of such environmental changes require officials to work more professionally by responding and accommodating public aspirations into government activities and programs.

Responsiveness is an organizational ability to recognize community needs, develop agendas and service priorities, and develop public service programs according to public needs and aspirations. Responsiveness relates to compatibility and alignment between programs and service activities with the needs and aspirations of the community. [3].

Responsiveness is a form of bureaucratic ability to anticipate and respond to new aspirations, new needs and new demands from society. [10].

The importance of realizing what has been responded to in the program and service activities is a form of bureaucratic obligation and neglect of it will have an impact on the disappointment of society which in turn may result in the emergence of a "crisis of confidence" to the government. The conclusion drawn by the author is that the responsiveness is the ability of the apparatus in looking at environmental changes (changing needs and public demands and technological advances) and reflect in the form of programs and services oriented to the community.

\section{Innovation}

Innovation is a continuation of a bureaucratic creativity through the existing response of environmental change. Innovation in the world of public bureaucracy often faces obstacles and clashes of the existence of formal rules and the low attitude of visionary leaders in the public bureaucratic environment.

Innovation shows that the bureaucracy finds and conducts new work processes aimed at making work and ministry better. A professional and modern organization strives to be customer-oriented and strives to encourage and respect the creativity of members, [13]. Conditions in which Indonesia's public bureaucracy today is faced with a work environment that is not conducive to the creation of 
innovation and lack of respect for creativity in it. Innovation not only aims to create a new working model but also aims to achieve a job satisfaction for individuals and organizations and service satisfaction for the community. Innovation is a desire and determination to always seek, discover and use new ways of working, new working methods, and new techniques in the implementation of work for the satisfaction of the work of the organization and community satisfaction. [11].

Actions and efforts to innovate especially in the world of bureaucracy of Indonesia need to get support and appreciation and eliminate all forms of obstacles such as highly procedural work processes and the presence of supertight supervision of the apparatus in performing the duties and functions of the organization by basing on the standard rules. The neglect of organizational values contained in the organization's vision and mission will only make the bureaucracy rigid and unresponsive to environmental change.

Based on the above explanation it can be concluded that innovation becomes very important and urgent to be done in order to face dynamic environmental changes and the importance of providing incentives for public bureaucracy including the apparatus in it to foster a positive competition climate where the apparatus can carry out the duties and organizational functions actively.

\section{Organization Goals}

The existence of a vision-mission is necessary for the organization to determine the direction and purpose of an organization. What is meant by "vision" is the future ideals that exist in the minds of the founders of an organization, and the definition of "mission" is concrete efforts pursued to realize that vision. What is meant by "organizational vision and mission is the expectation of the realistic, achievable and attractive future of the organization described in the mission as a statement for what the organization is built on. While the effective feature of an effective vision is to focus, clearly, contain something noble and the chances of success to achieve it are considerable. [12], [2].

The existence of a vision is required for each organization to determine the ideals to be achieved but these ideals should be realistic and not too normative. Vision is the guiding star for an organization including a country established for a particular purpose, it is not necessary to question who determines that goal but how to foster the same perception of all parties within the organization to achieve that goal by establishing mission as the main steps that must be carried out in the framework of achieving that goal. [11].

Good vision-mission is certainly the result of a togetherness in the organization and also adjust to the ability of individuals and financial capabilities of the organization. In order for the vision-mission of the organization does not become just wall decorations and organization cabinets it must be socialized to the apparatus to be applied into the implementation of duties and functions of the organization. Good missions express what products or services are produced, what needs are addressed, the goals of the service, how the quality of service is, and what the organization wants in the

future.

There are several mission-driven organizational advantages including: Organizations driven by missions "more efficient, more effective, more innovative, more flexible and more passionate than organizations driven by regulations. [9].

Based on the arguments of the experts above, it is concluded the importance of the existence of visionmission for the organization to determine what goals to be achieved by the organization in the future.

\section{Organization Structure.}

Structure for an organization is very useful to clarify and understand the tasks and functions of each section within an organization. With structure, the tasks of each part of the organization become clear. A good structure is a structure that oriented to organizational vision and mission that can ultimately improve organizational performance and professionalism of the ranks in it.

Organizational structure as a pattern and group of work within an organization. [5]. The organizational structure is a form of the way in which tasks and responsibilities are allocated to individuals, where individuals are grouped into offices, departments, and divisions. Organizational structure should always adjust to the development of public needs and the environment it aims to create an effective organizational performance and work processes fast.

The overly hierarchical organizational structure will only slow down the work process and tend to be inefficient. The existence of various tasks within the organization that must be completed requires the ability and skill of the apparatus. With a structure that divides the organization's tasks into group groups does not mean the structure becomes fragmented. The existence of cuttings is only a tool to show that an activity and work within the organization are on the box. the question is "when boxes or charts within the organization are broken down into smaller boxes" so that it only extends the hiraki within the organization that can impact the organization's inaction in completing tasks and jobs.

In order to achieve decentralized governance, it requires a lean organization that incorporates parts that share many similarities in tasks and functions, in which a lean organization and decentralized authority support make the organization flexible in responding, adapt quickly to change, more effective and innovative, and more commitment to the goal. The ideal structure for responding to environmental changes is a structure that allows organizations members to directly face the consumer and make decisions without going through hierarchical processes that are too long.

Organizational structures that are socially oriented can promote innovation that can be done by minimizing 
hierarchy, a considerable balance between the organization in standarkan and oriented to the market, [8]. To face the challenges ahead in the need for decentralization of authority to the region, to build a lean organizational structure whereby the decentralization of authority and lean structures allow for the organization to oriented the community, [2].

The importance of building an organizational structure that minimizes hierarchy and saves the layers or levels within the organization makes it possible for organizations to work effectively and quickly respond to public aspirations especially to accelerate decisionmaking within an organization to end the deadlock and complexity as a slow anticipation. One way to speed up the decision-making process in order to anticipate future shocks is to try to further strengthen the center of government, which adds more and more politicians, bureaucrats, experts and computers in the decision to run faster than acceleration of complexity; another way is to start reducing the burden of the decision by sharing it with more people, allowing more decisions to be made "down" or on the "edge" rather than concentrating on the stress-affected and inadequate center. [9].

Based on the opinions and explanations above it can be concluded that the organizational structure is able to show a positive contribution to the professionalism of its apparatus is a structure that allows for the delegation of authority from the top leadership to midfield management to mensikapi each job each part independently without having to go through the process of decision which is too long and awaits the instructions of the boss. The existence of delegation of authority and clear and firm division of tasks is expected to make the apparatus more professional and accountable to the public.

3. Leadership.

Leadership in organizations has an important role to achieve organizational goals. Through organizational leadership can mobilize all resources to achieve goals. Responsive leadership is necessary to create conditions conducive to organizational performance and mobilizing subordinates. Leadership is a change agent, people whose behavior will influence the behavior and performance of subordinates. [5].

Leadership is an activity to influence people to be directed toward the goals of the organization. Where the influence and ability of leaders in the opinion is very dominant for the achievement of organizational goals. [13]. Leaders with the authority possessed are expected to be able to lead subordinates and organize subordinates and minimize differences in interests between individual ambitions, or groups in achieving organizational goals. The same is also conveyed that leadership is the ability to encourage and invite others to do something to achieve common goals where leadership must meet certain competencies so that the process of achieving organizational goals becomes easier. These competencies include; acceptance / acceptance of groups, and the possession of special skills in one special situation, [7].

Based on the various opinions above it can be drawn a conclusion is the ability of a leader to place himself as an agent of change for organizations that can affect behavior and impact on improving organizational performance.

Leadership for some experts takes place and is selfgenerated and others claim that leadership is shaped through the environment. There are various theories about leadership, among others are: Talent Theory, That leadership begins from individual talents, but the talent must be developed by training themselves in certain traits and habits based on a theory about the mental attitude that must be possessed by a leader; Environmental theory, that certain times, periods, places, situations and conditions as a result of an important event, will present a leader desired by his environment at a given time; Theory of Personality Relationships with the situation, That one's leadership is determined by the personality that adapts to the situation and conditions faced in the form of tasks and occupations faced, the people who are led, the circumstances that affect the work as well as the people who must carry out the work, [6].

Leadership is not just formed, but leadership can be learned, where one can actually learn to become an executive and the most important characteristic of being a leader is an open, constant and constant learning. [5].

In leadership there are various forms of leadership, among others: Democratic Leadership, which is associated with the power of personnel and the presence of subordinate participation in the problems of the organization; Autocratic leadership, based on the power of position and use of authority. The fundamental difference between the two styles of leadership lies in the democratic leadership of working together, the leadership is respected and respected, the discipline is entrenched with volunteerism, the responsibilities are in the hands of all members, and communication is twoway and high cooperative spirit. [7].

The establishment of an ideal and democratic leadership is certainly not independent of certain competencies, [5] the competence that must be possessed by a leader at least meet the following 3 (three) elements: Intelligence, Supervision, Personality and Physical Character. Requirements to be met by a leader are: Physical vitality and stamina, intelligence and wisdom, great sense of responsibility, high spirit of success, aspiration, adaptability and flexibility, competence in the field, [15]. The fulfillment of such competence in a leader will give a positive meaning for a conducive working climate in achieving organizational goals. 


\section{Conclusion}

Based on the fact that there is in the world of bureaucracy reinforced by the arguments of experts it can be deduced that the professionalism of government officials is the key to success in the success of public service, while included in the professionalism of bureaucrats include:

1. Organizational culture that arises and crystallizes in the bureaucratic routine. Organizational culture is related to the daily practices in bureaucratic activities, if the custom built within the state apparatus in carrying out their duties with full responsibility and dedication will create a conducive atmosphere and there will be no bureaucratic pathology in government agencies .

2. Organizational goals. A good organizational goal is not a guarantee that the organization that runs will get good results without any cooperation, appreciation and a good understanding of the members of the organization. Therefore, it takes cooperation, awareness and reunderstanding of organizational goals in the run.

3. Organizational structure. Organizational structure is very useful to clarify and understand the tasks and functions of each section within an organization. With structure, the task of each part of the organization becomes clear. A good structure is a structure that is oriented towards the vision and mission of the organization that ultimately can improve the organizational performance and professionalism of the ranks in it.

4. Working procedures in bureaucracy. A long-winded work procedure will slow down the work system and confuse bureaucrats in carrying out their duties and responsibilities as community servants. Simple and easy to understand procedures for both applying and assigned officers to the public is one of the professional indicators of bureaucracy in running the public service system.

5. Application of system merit. Implementation of a good merit system will affect the performance patterns and morale of the state apparatus in a professional competition.

\section{References}

[1] Ancok, Djamaluddin. Revitalisasi SDM Dalam Menghadapi Perubahan Pada Pasca Krisis, 1999

[2] Ancok, Djamaluddin. Manajemen SDM. 2000.

[3] Dwiyanto, Agus. Kinerja Organisasi Publik, kebijakan dan Penerapannya. 1995.

[4] Dwiyanto, Agus. Mengembalikan Kepercayaan Publik Melalui Reformasi Birokrasi. Gramedia, Jakarta, 2011.

[5] Gibson, Ivancevich, Donnelly. Organizations. Richard. D. Irwin. Inc.,1995.

[6] Karjadi, M. Kepemimpinan (Leadership). PT. Karya Nusantara, Bandung, 1989.

[7] Kartono, Kartini. Pemimpin dan kepemimpinan, Grafindo, Jakarta, 1998.

[8] Negal, Kurt. The Six Key To Company Succes, Elex Media Komputindo, Jakarta,1995. (terjemahan).

[9] Osborne, David \& Gaebler, Ted. Mewirausahakan Birokrasi. PPM, Jakarta, 1992.

[10] Siagian, P Sondang. Patologi Birokrasi. Galia Indonesia, Jakarta, 1994.

[11] Siagian, P Sondang. Administrasi Pembangunan. Bumi Aksara, Jakarta, 2000.

[12] Sri Wahyudi, Agustinus. Manajemen Strategik: Pengantar Proses Berfikir Strategis. Binarupa Aksara, Jakarta, 1996.

[13] Thoha. Miftah. Perilaku Organisasi. Rajawali Pers, Jakarta, 1999.

[14] Tjokrowinoto, Muljarto. Pembangunan, Dilema dan Tantangan. Pustaka Pelajar, Yogyakarta,1996.

[15] Utomo, Warsito dan Abidin, Zainal. Hand Out Analisis Organisai Publik. MAP-UGM, Yogyakarta,1998. 